\title{
Modeling the Competitive Advantage of Iranian Soccer Clubs Based on the Team Reputation Considering the Satisfaction Level of Fans of the Selected Teams
}

\author{
${ }^{1}$ Mohammad Deheshti, ${ }^{1}$ Seyyed Morteza Azimzadeh ${ }^{*},{ }^{1}$ Zahrasadat Mirzazadeh, \\ ${ }^{2}$ Hossein Alimohammadi \\ ${ }^{1}$ Department of Sport Manegement, Faculty of Physical Education \&Sport Science, Ferdowsi University \\ of Mashhad, Mashhad, Iran. ${ }^{2}$ Department of Physical Education and Sport Sciences, University of Qom, \\ Qom, Iran.
}

Submitted 16 December 2018; Accepted in final form 15 February 2019.

\begin{abstract}
Background. Today, all the fields, including science, business, industry, and sports, are influenced by the profound and sustained changes. New rules arise every day; organizations, especially sports clubs, are in an endless struggle to gain competitive advantage in the battle for survival and power stealth. The main function of competitive advantage is to guarantee the survival of organizations, so that they can succeed in their path to developments. Objectives. This study is a field research aimed to model the competitive advantage of Iranian Soccer Clubs based on the team reputation considering the satisfaction level of fans. Methods. The statistical population of the study included the fans of the teams of Iranian Premier League (2017-2018), among which 384 fans were selected as the sample. The measurement tool included the questionnaires of the public relations, brand image and identity, satisfaction, team reputation, and competitive advantage. Validity and reliability of the questionnaires were confirmed by experts using the Fuzzy Delphi Method (FDM) and Cronbach's alpha test. The descriptive statistical tests including the central tendency, dispersion, and inferential statistics (the structural equation test) were used for data analysis. SPSS software version 19 was used for the descriptive analysis and LISREL software for the analysis of the structural equation modeling. Results. The variables of public relations, brand identity, and brand image have a positive and significant effect on the team reputation. Also, satisfaction level of fans has a positive and significant effect on the competitive advantage of soccer clubs. Conclusion. The findings confirmed the significance of the conceptual model of the research. However, more studies should be conducted to identify other dimensions influencing the competitive advantage of teams.
\end{abstract}

\section{KEY WORDS: Team Reputation, Competitive Advantage, Football Team, Fan.}

\section{INTRODUCTION}

In order to dominate their power on the market, organizations seek to use new rules before their competitors. There is an endless competition for gaining the competitive advantage. Hence, the first and most important function of the competitive advantage is to ensure the survival of organizations (1). In 1965, Alderson stated that companies should look for features that can distinguish them from other competitors (2). Competitive advantage means that a company can produce goods or services that are more valuable from the customers point of

*. Corresponding Author:

Seyyed Morteza Azimzadeh, Assistant Professor

Department of Sport Management, Faculty of Sport Sciences, Po.Box: 9177948979, Ferdowsi University of Mashhad, Azadi Sq.,

Mashhad, Iran.

E-mail: mortezaazimzade@um.ac.ir 
view he compared to the goods and services provided by other competitors. Organizations can achieve quality in a variety of ways, which is one of the factors influencing the competitive advantage (3). There is a competitive advantage in both tangible and intangible resources, where organizational reputation is one of the key factors influencing the intangible competitive advantage in organizations, teams, or sports clubs.

Researchers have introduced some theories about the organizational reputation, which are used as a framework for the organizational reputation (4). Fumberan considers organizational reputation as a combination of four attributes of credibility, trust, trusteeship, and responsibility (5). Since reputation is an intangible asset which guarantees the survival of an organization, it has attracted the interest of many researchers in recent years (6). Reputation is a key goal in the sports industry, and therefore, sports organizations tend to work hard to increase their reputation (7). Jang and Chan (2015) presented 6 dimensions including team performance, traditions governing the team, social responsibility, fan-centeredness, managerial quality, and financial health of the team for the reputation of sports teams. Several factors have been identified as the relevant and influential factors influencing the reputation of sports teams, including the public relations of sports organizations, brand identity and brand image of the team (8). Regarding the organizational reputation, public relations includes the two dimensions of the activities on the social relations and media relations (9). Media plays a significant role in creating brand and organizational reputation for the sports organizations and clubs (10). Carvalho (2004) argued that successful organizations had a good performance in public relations and extensive communication with the stakeholders (11). Also, Courtright and Smudde showed that the use of communications and perceptions plays an important role in creating innovation to improve the reputation management (12).

Bround (2006) states that studies on brand identity and brand image include the two organizational and individual levels; the goal of the individual level is to know about the opinions of stakeholders about an organization (13). Brand identity and image are closely related to the organizational reputation and therefore, they are sometimes considered the same and this can be confusing. The definition of reputation depends on the way that other key elements, such as the brand identity and image are defined; reputation is often considered synonymous with the image (12). Tracey (2014) identified some of the obvious constraints on corporate reputation; among these is the confusion and contradiction in the concept of reputation and its close relationship with some of other subjects, including the brand image and identity (14). The brand identity is the image of a brand that a company wants to possess, which is the ideal image of a favorable brand (15). The starting point of the corporate reputation is the corporate identity which reflects a company's characteristics which are in turn reflected in the domestic culture and corporate values. Carvalho (2004) stated that the image of an organization or a sports club is created through the experiences gained by the provided products or services and the messages sent by this organization, while the reputation of organizations will be created through the behavior of managers and public relations (11).

Brand image is the first word or image that comes to the customers' mind immediately after hearing the brand's name. The aim of focusing on the brand image is to ensure that consumers have a proper attitude towards the brand. Researchers believe that the higher level of brand reputation is more likely to lead to a higher satisfaction level and brand loyalty (15). The findings of Courtright and Smudde (2009) indicated that there is a relationship between the public relations and message content and the brand identity and image to enhance the organizational reputation. Hence, the image that audiences have from a corporation' brand should be upgraded (12). In order to enhance the reputation and brand image, football clubs are trying to promote their cultural, social, and economic status (16). Football has become a big industry and business rather than a way of entertainment; it is not just about winning and losing in a game, but it also is a ground for making money. Hence, attracting a powerful financial investor or a new sponsorship contract by sports club is sometimes of great importance. A review of the literature indicates the importance of the fame and reputation of organizations and sports clubs for gaining the competitive advantage and profitability. A review of previous studies also shows that there is no comprehensive research 
investigating the variables that influence the competitive advantage, and each of them has investigated one of these variables. Given the multiplicity of factors influencing the competitive advantage, it is necessary to have a more comprehensive view of them. Therefore, the conceptual model of this study attempts to investigate the causal relationships between the variables influencing the competitive advantage comprehensively. In this model, the components of public relations, brand identity and image, team reputation, and fans satisfaction are considered as the independent variables influencing the competitive advantage of Iranian soccer clubs which are studied in this study (Figure 1).

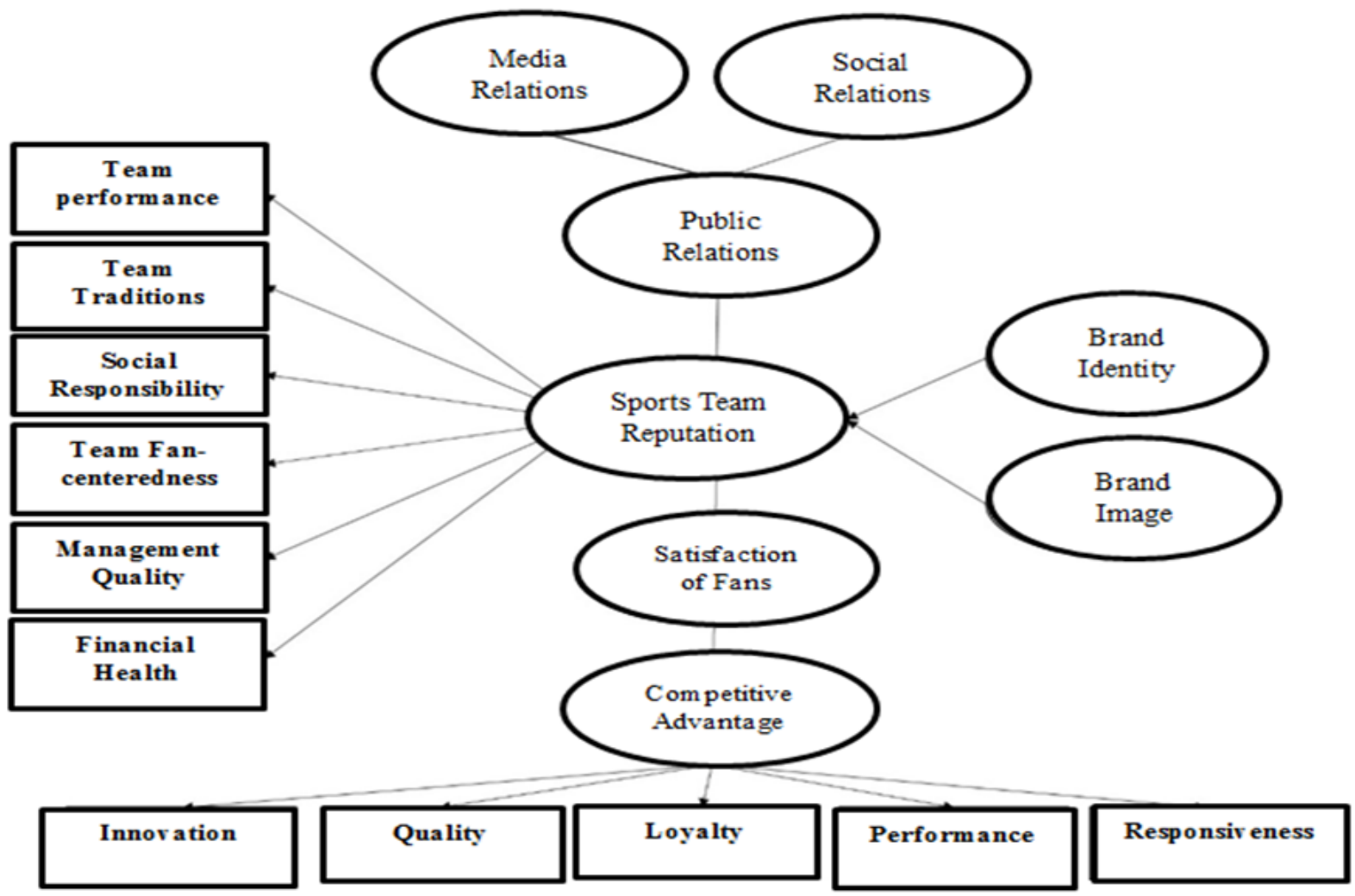

Figure 1. Conceptual Model of the Research

\section{MATERIALS AND METHODS}

Research Design. The present study is an applied, descriptive-correlative research in which the field data collection method was applied. In order to analyze the collected data, measures of central tendency and dispersion were used in the descriptive statistics section, and the Kolmogorov-Smirnov tests were used in the inferential section to investigate the distribution status of the data, confirmatory factor analysis and structural equations were used for the stabilization of the assumed variables and the discovery of latent variables. It should be noted that all research hypotheses were studied at the significance level of 0.05 using the statistical software of SPSS V.19 and LISREL software.

Participants. The statistical population of this study included the two groups. The first group comprised of all managers and experts in the field of strategic management, organizational reputation, and sports management in Iran. After a review of the literature, 100 people were identified among those who had activity in academic research including publishing papers, books or authentic manuscripts in the abovementioned fields. Then, 60 experts were invited to participate in the two-step Delphi method, and 25 of them were entered into the Delphi phase. The purposive sampling method was applied in the Delphi phase. The second group consisted of 
the fans of some teams in Iran's Premier League (2017-2018). The fans were selected among the fans of teams such as Persepolis, Esteghlal, Tractor, Sepahan, Zobahan, and some of other teams. The sample size included 384 individuals based on Morgan's Table.

Instrumentation: The measurement tools consisted of the modified questionnaires of team reputation (based on the standard questionnaires of the organizational reputation developed by Fumberan and Venrill (2003)), competitive advantage (based on the standard questionnaire of competitive advantage developed by Hill and Jones (2014) $(17,18)$ ), and the researcher-made questionnaires of public relations, brand image, brand identity, and satisfaction, which were confirmed by the experts in the two stages of Delphi. The final questionnaires of the study included the demographic questionnaire, the team-reputation questionnaire (including the 6 dimensions of performance, governing traditions, social responsibility, fancenteredness, management quality, and financial health with 18 items), the competitive advantage questionnaire (including the 5 dimensions of efficiency, quality, innovation, responsiveness, and support of fans with 33 items), the public relations questionnaire (including the two dimensions of media relations and social relations with 8 items), and the questionnaires of brand image (3 items), brand identity (4 items), and satisfaction (14 items).

Validity and Reliability of the Tools: The content and face validity of the questionnaires was confirmed by a survey of 25 experts using the Delphi method. The assumption of consensus among experts about each component was to achieve a minimum score of 0.7 for that component. Also, the internal consistency reliability of questionnaires through Cronbach's alpha test was as follows: public relations: 0.80 , brand image: 0.85 , brand identity: 0.85 , team reputation: 0.95, competitive advantage: 0.96, and fans' satisfaction: 0.94 .

\section{RESULTS}

The descriptive findings showed that $25.5 \%$ of participants were female and $74.5 \%$ were male. In terms of age, $13.5 \%$ were below 20 years old, $46.5 \%$ were between 20-30years old, $12.5 \%$ were between $31-40$ years old, $4.4 \%$ were above 41 years old, and $23.1 \%$ of them did not answer to this question. $70.4 \%$ of the participants were single and $29.6 \%$ were married. Regarding the educational level, $29.1 \%$ of them had a diploma, $14 \%$ of them had an undergraduate degree, $39.2 \%$ had a bachelor's degree, $16.1 \%$ had a master's degree, and $1.6 \%$ had a Ph.D. degree. Regarding the support of sports teams by the respondents, $37.4 \%$ of the participants were fans of Esteghlal, 54.5\% were fans of Persepolis, 3.4\% were fans of Tractor, $2.3 \%$ were fans of Sepahan, $1 \%$ was fan of Zobahan, and $1.3 \%$ of them were fans of other teams. Also, the way participants follow the matches of their favorite teams was as follows: $88.1 \%$ was through watching television, $4.2 \%$ was through attendance in the stadium, 6\% was through surfing on the Internet, and $1.8 \%$ was through listening to the radio.

The results of investigating the conceptual model of the study and the relationship between the variables in the model are presented in the two modes of coefficients of significance and standard path coefficients which are shown in Fig. 2 and Tables 1 and 2.

Based on the results of Figure 2, the coefficients related to the relationship between each of the variables in the conceptual model are presented.

Based on the results presented in Table 1, all indicators are in a very favorable and satisfactory level and this indicates a suitable fitness of the model of the study. Therefore, the conceptual model of the research is confirmed based on the structural equation modeling. The coefficients related to the causal relationship of the variables of the model are presented in Table 2.

Based on the results of Table 2, there is a significant causal relationship between the various variables of the model including the public relations, brand identity and image and the team reputation; the reputation and satisfaction; satisfaction and competitive advantage; and reputation and competitive advantage. 


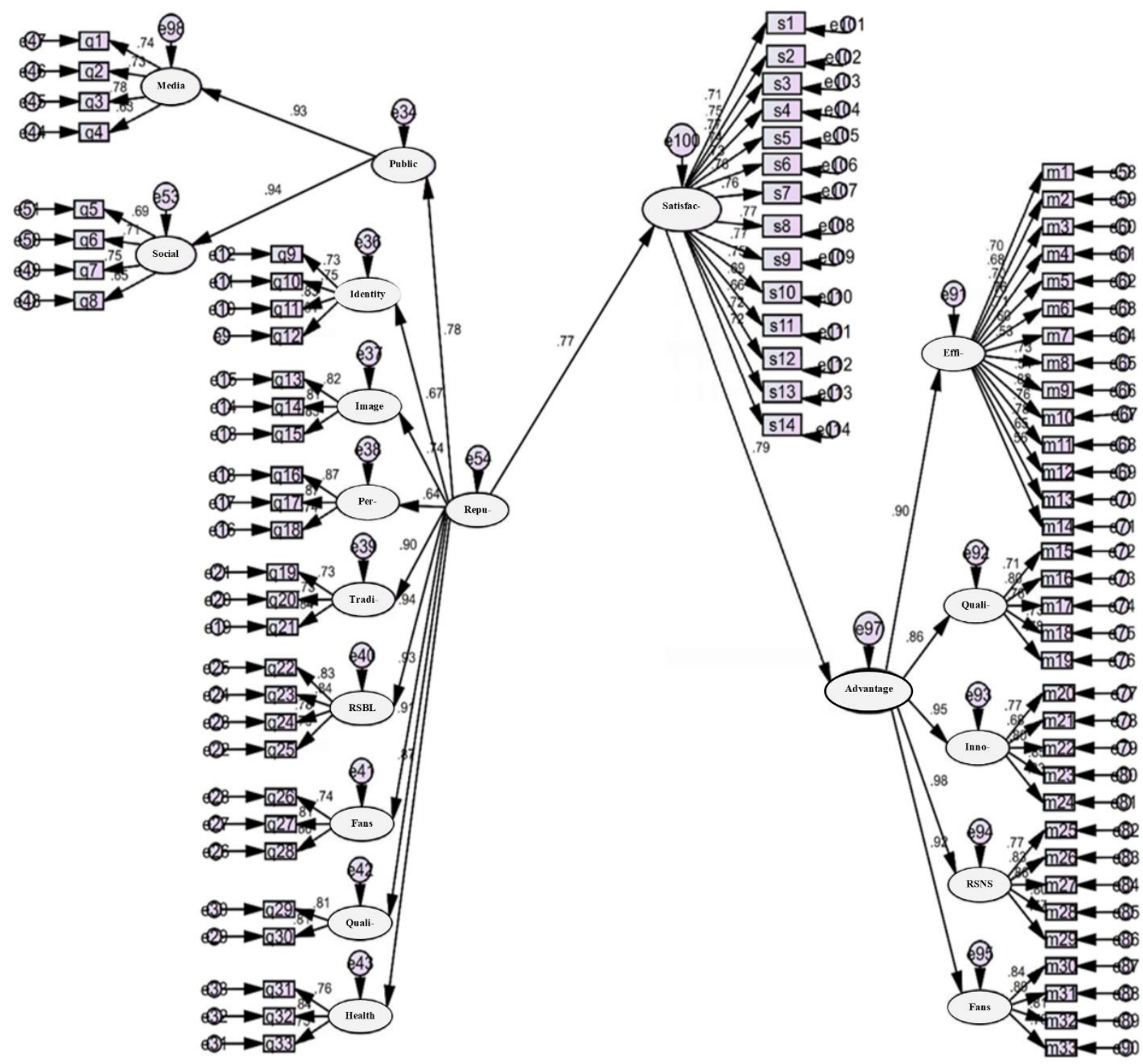

Figure 2. The Structural Equation Modeling developed for the standard estimation of the relationship between the variables in the conceptual model. Per-: Performance; Repu-: Reputation; Tradi-: Tradition; RSBL: Responsibility; Quali-: Quality; Satisfac-: Satisfaction; Effi-: Efficiency; Inno-: Innovation; RSNS: Responsiveness.

Table 1. Goodness of Fit Indexes for the general research model based on the variables of public relations, brand identity and image, team reputation, satisfaction, and competitive advantage

\begin{tabular}{ccccc}
\hline $\begin{array}{c}\text { Goodness of Fit } \\
\text { Indexes }\end{array}$ & Acceptable values & Great values & Research values & $\begin{array}{c}\text { Goodness of Fit } \\
\text { Result }\end{array}$ \\
\hline$\chi^{2} / \mathrm{df}$ & $3 \leq$ & $2 \leq$ & 2.28 & good fit \\
RMSEA & $0.1 \leq$ & $0.08 \leq$ & 0.062 & great fit \\
NFI & $0.9 \geq$ & $0.95 \geq$ & 0.91 & good fit \\
CFI & $0.9 \geq$ & $0.95 \geq$ & 0.90 & good fit \\
GFI & $0.9 \geq$ & $0.95 \geq$ & 0.90 & good fit \\
RMR & $0.08 \leq$ & $0.05 \leq$ & 0.08 & good fit \\
\hline
\end{tabular}

RMSEA: Root Mean Squared Error of Approximation; NFI: Normed Fit Index; CFI: Comparative Fit Index; GFI: Goodness of Fit Index; RMR: Root Mean Square Residual. 
Table 2. The results of testing the hypotheses

\begin{tabular}{lcc}
\hline The Path of the Hypotheses & Path coefficient & Result \\
\hline Public relations have a positive and significant effect on the team reputation. & $0.78^{*}$ & confirmed \\
The brand identity of the club has a positive and significant effect on the team reputation. & $0.67^{*}$ & confirmed \\
The brand image of the club has a positive and significant effect on the team reputation. & $0.74^{*}$ & confirmed \\
Team reputation has a positive and significant effect on the satisfaction level of fans. & $0.77^{*}$ & confirmed \\
Team reputation has a positive and significant effect on the competitive advantage. & $0.58^{*}$ & confirmed \\
Fans' satisfaction has a positive and significant effect on the competitive advantage. & $0.79^{*}$ & confirmed \\
\hline *: p<0.001 & &
\end{tabular}

\section{DISCUSSION}

The present study aimed to investigate and analyze the conceptual model of the research based on the variables of public relations, brand identity and image, team reputation, satisfaction of fans, and competitive advantage. The results of the structural equations indicated a good fitness of the investigated variables in the research model. The results showed that public relations and brand image of the team have a positive and significant effect on the team reputation. In this regard, the study by Carvalho (2004) indicated the key role of public relations management in the organizational reputation management. Successful organizations have a good performance in the management of media relations and social relationships. The abovementioned study is the closest research to the present study, which explicitly confirms the relationship between the components of public relations (including the media and social relations) and the corporate reputation management. From Carvalho's point of view, the content of the produced message and its representation in both media and society plays a key and vital role in the organization (11). Hence, football clubs (as companies providing services) should also be sensitive about the content of messages they publish in the community and media and deal with this issue in a professional manner, so that to enhance the club reputation as well as to prevent undesirable messages which may undermine the club reputation. This means that individuals who are employed in the positions of public relations should be welltrained and possess necessary communication skills in dealing with the media and target groups in order to adopt appropriate communication strategies for each type of strategy. In addition, according to Courtright and Smudde (2009), there is a relationship between the public relations and content of the message and the concepts of brand identity and image to enhance the reputation of the organization. In the process of producing and distributing the content of messages to the fans of football clubs, brand identity and image should be enhanced and damaging to them should be prevented (12).

The findings also suggest that the team's brand identity and image have a positive and significant effect on the team reputation, which can ultimately lead to the competitive advantage. In this regard, Amis (2003), investigated the ways of using sports in the management and development of intangiable resources such as the brand image and reputation, showed that they are two key factors in the development of competitive advantage. Using the qulitative data collected from different sources, including the interviews, videos, documents, internal lectures, electronic media, the press, and various scientific publications, he introduces sports as a business which can play an important role in the development of the image and reputation of different organizations through the direct sponsorship, advertising, and business promotion techniques (19). The above-mentioned contents indicate the importance regarding paying attention to the achievement of team reputation by the management of sports organizations; this can be achieved through the development of brand identity and image of sports teams in order to gain reputation and competitive advantage. Another finding of the present study is the relationship between the team reputation and the satisfaction of fans and gaining competitive advantage. Lack of team reputation undermines the sense of fans' belonging to the club and reduces their satisfaction level, club support, and commitment to the club's values and goals. Therefore, lack of team reputation can bring about dissatisfaction of 
fans and the loss of competitive advantage for the club, and ultimately, this may threaten the existence of a sports organization in a dynamic and competitive environment. The increasing awareness regarding the importance of the team reputation management and obtaining fans satisfaction is of great importance for the directors and managers of teams and sports clubs in order to pave the way for gaining competitive advantage. Witzig (2011) showed that there is a significant relationship between the social responsibility (as one of the components of reputation) of sports teams and the fans satisfaction and gaining competitive advantage, and this issue should not be neglected by the managers of football clubs. It seems that it is possible to consider this issue through the benevolent games and observance of environmental issues and other matters (20). Anderson and Sullivan (1993) claimed that the higher level of customers satisfaction brings a positive reputation, and in this case, reputation is considered as one of the consequences of satisfaction. They found that reputation is positively correlated with the satisfaction and loyalty. Therefore, in order to gain competitive advantage, more attention should be paid to the satisfaction level of the fans through considering the team reputation (21).

Although the present study introduced the fan's satisfaction as a mediator variable in gaining the competitive advantage, there are various studies investigated the effect of club reputation components on the competitive advantage, each of which reflected just a part of this relationship. Among these components are the performance (Zhang, 2009; Ozturk et al., 2010; Tracey, 2014) $(14,22,23)$, the tradition governing the club (Tracey, 2014) (14), social responsibility (Zhang, 2009; Ozturk et al., 2010; Witzig, 2011; Bhiwandi et al., 2012; Heinz, Souderesturom \& Zedrovik, 2014; Tracey, 2014) (14, 20, 22-25), and the quality of management (Bar \& Ellie, 2008; Ozturk et al., 2010; Tracey, 2014) (14, 22, 26). Furthermore, Jang and Chan (2015) argued that reputation directly and indirectly influences customer variables such as the trust, satisfaction, verbal behavior, and loyalty (8). Although many companies consider the needs of their customers, few of them pay attention to their customers' satisfaction in the sales units exclusively, while many sales units focus on the reduction of costs.
Companies which are customer-oriented in practice try to place customers satisfaction in the top priority of all of their units. For such companies, the provision of services that are subject to consumer judgment is of great importance, and therefore, customer feedback plays an important role in these organizations. Therefore, in order to achieve a competitive advantage through the customer's satisfaction, it is important for an organization to be aware of the factors influencing customers satisfaction (27). The findings of the present study are consistent with the study conducted by Helm, indicated the role of reputation, and of course its components, leading to the customer loyalty as a strategic competitive advantage (28). It should be noted that the success and competitive advantage of soccer clubs can be achieved through the fans satisfaction and reputation of sports teams, and reputation can be considered as a factor predicting the competitive advantage (29). In other words, reputation of a team or a soccer club can lead to the competitive advantage of this club among other clubs. Therefore, managers of football clubs should act like other well-known organizations, investing in this intangible and non-copyrighted section in order to be more successful in obtaining the competitive advantage through the team reputation (30).

\section{CONCLUSION}

The results of the structural equation model indicate an effective and acceptable effect of team reputation on the competitive advantage; this shows that the attention of the football clubs to the improvement and increasing the team reputation, through increasing the fans satisfaction, can have a positive effect on the competitive advantage of clubs. Acquiring team reputation and increasing it requires considering the variables of public relations, brand identity, and brand image; since these variables have a direct effect on the team reputation. Lack of attention to public relations results in the reduced influence and reputation of sports teams at the community level and this has a negative effect on the reputation of teams and leads to a decrease in the satisfaction level of fans. As, based on the results of this study, since fans satisfaction is an effective factor leading to the increase in the competitive advantage, football clubs should focus on increasing the satisfaction level of fans. It seems that football clubs should 
have a more comprehensive view of the variables influencing their competitive advantage, and consider all aspects of competitive advantage at the same time. Mere consideration of one aspect may hinder attention to other influential aspects, and ultimately this reduces the competitive advantage of the club. In case of explaining the competitive advantage model of the football clubs, the lack of access to the fans of all teams was one of the limitations of this research and therefore, it is suggested to include the fans of all football teams in the Premier League for the future studies.

\section{REFERENCES}

1. Potocan V. Marketing Capabilities For Innovation-based Competitive Advantage in the Slovenian Market. Innovative Issues and Approaches in Social Sciences. 2013;6(1):118-35. [DOI:10.12959/issn.1855-0541.IIASS2013-no1-art07]

2. Hoffman NP. An examination of the" sustainable competitive advantage" concept: past, present, and future. Academy of marketing science review. 2000;4(2000):1-16. [DOI:10.1287/mksc.19.1.1.15181]

3. Sarjana S, Khayati N. The Role of Reputation for Achieving Competitive Advantage. 2017. [DOI:10.2991/icbmr17.2017.30]

4. Javaran SH, Sajadi SAN, Karamoozain M. The relationship between the social responsibility of club with reputation and fans' dependency on the team in the football premier league. 2014.

5. Gardberg NA, Fombrun CJ. Corporate citizenship: Creating intangible assets across institutional environments. Academy of management Review. 2006;31(2):329-46. [DOI:10.5465/amr.2006.20208684]

6. Chun R. Corporate reputation: Meaning and measurement. International Journal of Management Reviews. 2005;7(2):91-109. [DOI:10.1111/j.1468-2370.2005.00109.x]

7. Barton J. Who cares about auditor reputation? Contemporary accounting research. 2005;22(3):549-86. [DOI:10.1506/C27U-23K8-E1VL-20R0]

8. Jang W, Jae Ko Y, Chan-Olmsted SM. Spectator-based sports team reputation: scale development and validation. International Journal of Sports Marketing and Sponsorship. 2015;16(3):52-72. [DOI:10.1108/IJSMS-16-03-2015B005]

9. Kiousis S, Popescu C, Mitrook M. Understanding influence on corporate reputation: An examination of public relations efforts, media coverage, public opinion, and financial performance from an agenda-building and agendasetting perspective. Journal of Public Relations Research. 2007;19(2):147-65. [DOI:10.1080/10627260701290661]

10. Gill R. The Influence of Media Platforms on Sport Reputation: An Australian Football League Case Study. Journal of Sports Media. 2018;13(1):123-51. [DOI:10.1353/jsm.2018.0005]

11. Carvalho Rd. Reputation management as relationship management. 2004.

12. Courtright JL, Smudde PM. Leveraging organizational innovation for strategic reputation management. Corporate Reputation Review. 2009;12(3):245-69. [DOI:10.1057/crr.2009.18]

13. Foroudi P. Influence of brand signature, brand awareness, brand attitude, brand reputation on hotel industry's brand performance. International journal of hospitality management. 2019;76:271-85. [DOI:10.1016/j.ijhm.2018.05.016]

14. Tracey NP. Corporate reputation and financial performance: Underlying dimensions of corporate reputation and their relation to sustained financial performance: Queensland University of Technology; 2014.

15. Deheshti M, Firouzjah JA, Alimohammadi H. The Relationship between Brand Image and Brand Trust in Sporting Goods Consumers. Annals of Applied Sport Science. 2016;4(3):27-34. [DOI:10.18869/acadpub.aassjournal.4.3.27]

16. SSener İ, Karapolatgil AA. Rules of the Game: Strategy in Football Industry. Procedia-Social and Behavioral Sciences. 2015;207:10-9. [DOI:10.1016/j.sbspro.2015.10.143]

17. Fombrun C, Cees V. Fame \& Fortune: How successful companies build winning reputations. financial times prentice hall books. Upple Saddle River, NJ. 2003.

18. Hill CW, Jones GR, Schilling MA. Strategic management: theory: an integrated approach: Cengage Learning; 2014.

19. Amis J. "Good things come to those who wait": The strategic management of image and reputation at guinness. European sport management quarterly. 2003;3(3):189-214. [DOI:10.1080/16184740308721950] 
20. Vitezić N. Correlation between social responsibility and efficient performance in Croatian enterprises. Zbornik radova Ekonomskog fakulteta u Rijeci: časopis za ekonomsku teoriju i praksu. 2011;29(2):423-42.

21. Anderson EW, Sullivan MW. The antecedents and consequences of customer satisfaction for firms. Marketing science. 1993;12(2):125-43. [DOI:10.1287/mksc.12.2.125]

22. Ozturk Y, Cop S, Sani RA. The Effect of corporate reputation management as a competition tool on tourism businesses. 2010.

23. Zhang Y. A study of corporate reputation's influence on customer loyalty based on PLS-SEM model. International Business Research. 2009;2(3):28. https://doi.org/10.4018/jebr.2006070103 [DOI:10.5539/ibr.v2n3p28]

24. Bayoud NS, Kavanagh M, Slaughter G. Corporate social responsibility disclosure and corporate reputation in developing countries: the case of Libya. Journal of Business and Policy Research. 2012;7(1):131-60.

25. Heinze KL, Soderstrom S, Zdroik J. Toward strategic and authentic corporate social responsibility in professional sport: A case study of the Detroit Lions. Journal of Sport Management. 2014;28(6):672-86. [DOI:10.1123/JSM.2013-0307]

26. Bar-Eli M, Galily Y, Israeli A. Gaining and sustaining competitive advantage: on the strategic similarities between Maccabi Tel Aviv BC and FC Bayern München. European journal for sport and society. 2008;5(1):73-94. [DOI:10.1080/16138171.2008.11687810]

27. Massawe D. Customer satisfaction and complaints as a means of gaining a competitive advantage in hospitality industry. The Eastern African Journal of Hospitality, Leisure and Tourism. 2013;1(1):1-10.

28. Helm S. The role of corporate reputation in determining investor satisfaction and loyalty. Corporate Reputation Review. 2007;10(1):22-37. [DOI:10.1057/palgrave.crr.1550036]

29. Kotler P, Gertner D. Country as brand, product, and beyond: A place marketing and brand management perspective. Journal of brand management. 2002;9(4):249-61. [DOI:10.1057/palgrave.bm.2540076]

30. Cabral L. Living up to expectations: Corporate reputation and sustainable competitive advantage. 2012. 